\title{
Assessment of factors affecting the performance of concrete cutting of building structures
}

\author{
Andrey Kossolapov* \\ Moscow State University of Civil Engineering, Yaroslavskoe shosse, 26, Moscow, 129337, Russia
}

\begin{abstract}
Analyze of influence factors on performance during concrete sawing and drilling is given on base of more than twenty five years of collecting data on job sites. Those coefficients are showing how productivity of labor declines due to influence of various factors. Numerical coefficients give planners opportunity to make draft time calculation and include concrete drilling and sawing in projects even having no experience in such technology at all.
\end{abstract}

One of main indicators of efficiency of technology process is time of fulfillment of job. It is sufficient for concrete drilling and sawing technology. In order to receive numerical meanings researches of factors of influence were conducted.

First of all were named and studied factors of influence. Most important of factors are following: weather factor (temperature of air), cramped conditions of work (dimensions of working space), work from scaffolding or ladder (height, distance from floor), reinforcement of concrete in plane of cut (relation of cut reinforcement square to the full square of cut or drill cylinder sweep area), the direction of drilling (for drilling and disc sawing only) and depth of cut (for wall sawing only).

Researchers conducted on statistic base collected by author on more than 200 job sites during 25 years and experimentally.

To determine the magnitude of the influence of this group of parameters, we introduce a General coefficient of decline in labor productivity. The coefficient is derived empirically and refined based on the analysis of experimental data:

$$
k_{d e c}=k_{w} \cdot k_{c c} \cdot k_{d} \cdot k_{h} \cdot k_{r} \cdot k_{d d}
$$

$k_{w}$ - factor taking into account the complexity of work in difficult temperature conditions;

$k_{c c}$ - factor taking into account the work in difficult cramped conditions;

$k_{h}$ - factor taking into account the complexity of work at height;

$k_{r}$ - the coefficient of reinforcement, taking into account the increase in complexity during the cutting of concrete with different saturation of reinforcement falling into the cutting plane;

$k_{d^{-}}$coefficient of performance versus depth of cut;

$k_{d d}$ - coefficient of direction of drilling.

${ }^{*}$ Corresponding author: info@ naars.ru 
Consider each of the coefficients presented.

Performance of works at air temperature in the range from -5 to $+25 \mathrm{C}^{\mathrm{o}}$ can be considered comfortable for operator and machinery because no additional activities required. Negative values of the ambient temperature (from -5 to $-25 \mathrm{C}^{\circ}$ ) additional activities are becoming necessary. This requires additional working time for the organization and maintenance of hot water, additional time for heating the operator, additional time for a complete drain of water and purging the drilling system when moving to another gripper, etc. In the production of works at elevated temperatures, the value of the coefficient also changes with increasing air temperature. Under these conditions, the decrease in productivity is due to overheating of the equipment (with each rearrangement of the equipment there is an expansion of hydraulic fluid in the hoses experiencing the heating effect of direct sunlight). To install the equipment on the next hook, the pressure relief in each of the closed hydraulic hoses is required, since the increased pressure prevents the connection of the hydraulic connectors. At temperatures above $30{ }^{\circ} \mathrm{C}$ significantly reduces the performance of the human brain, slows down the reaction and the ability to process information. For the operator working with equipment that is dangerous to himself and others, it is necessary to regularly interrupt the work and make a short rest in a cool room. The coefficient values are given in table 1 .

Table 1. Coefficient according to temperature conditions $k_{w}$

\begin{tabular}{|c|c|c|c|}
\hline \multirow{2}{*}{ Temperature,${ }^{\circ} \mathrm{C}$} & $k_{w}$ & Temperature, ${ }^{\circ} \mathrm{C}$ & $k_{w}$ \\
\hline 0 & 1,0 & +25 & 1,0 \\
\hline-5 & 0,9090 & +30 & 0,9090 \\
\hline-10 & 0,8333 & +35 & 0,8333 \\
\hline-15 & 0,7692 & +40 & 0,7692 \\
\hline-20 & 0,7142 & +45 & 0,7142 \\
\hline-25 & 0,6666 & +50 & 0,6666 \\
\hline
\end{tabular}

$k_{c c}$ - factor that takes into account the work in difficult cramped conditions. The value of the coefficient depends on the degree and type of constraint (restriction on height, width or length of the room). Even given the high modularity of the equipment, working in cramped conditions leads to reduced productivity. This is due not only to additional operations in the process of installation and dismantling of equipment and diamond tools, but also additional inconveniences during cutting or drilling, as for the control of the workflow process access to the work area is significantly limited. All of this results in poor performance. The coefficient values are given in table 2.

Table 2. Coefficient according to cramped conditions $k_{c c}$

\begin{tabular}{|c|c|}
\hline The size of the working area (width, length, height), $\mathrm{m}$ & $k_{c c}$ \\
\hline $2,00 \times 2,00 \times 3,00$ & 0,9090 \\
\hline $2,00 \times 2,00 \times 2,50$ & 0,8333 \\
\hline $2,00 \times 2,00 \times 2,00$ & 0,7692 \\
\hline $1,50 \times 2,00 \times 2,00$ & 0,7142 \\
\hline $1,50 \times 1,50 \times 2,00$ & 0,6666 \\
\hline $1,50 \times 1,50 \times 1,50$ & 0,6250 \\
\hline $1,00 \times 1,50 \times 1,50$ & 0,5882 \\
\hline
\end{tabular}


$k_{h^{-}}$coefficient, taking into account the complexity of the work at height. When installing and dismantling equipment at a height of more than $2 \mathrm{~m}$ from the floor surface there is a need to use various AIDS to perform work at height. These include scaffolding, stepladder, tours, etc. Work on the installation and dismantling of diamond equipment from the stairs is prohibited by safety regulations. The number and set of operations for installation and fixation of equipment at height are significantly changed. The increase in working time is also caused by the additional time spent by the operator on multiple ascents and descents from the height of the location of the work site during the entire drilling process. The coefficient values are given in table 3.

Table 3. Coefficient according to height $k_{h}$

\begin{tabular}{|c|c|}
\hline Height, $\mathrm{m}$ & $k_{h}$ \\
\hline 2,00 & 1,0 \\
\hline 3,00 & 0,9523 \\
\hline 4,00 & 0,9090 \\
\hline 5,00 & 0,8695 \\
\hline 6,00 & 0,8333 \\
\hline 7,00 & 0,8000 \\
\hline
\end{tabular}

$k_{r}$ - the coefficient of reinforcement, taking into account the increase in complexity during the cutting of reinforced concrete with different saturation of reinforcement falling into the plane of the cut. A deeper investigation of the effect of reinforcement concrete at the time of execution of works on the diamond cutting has shown the necessity of making the updated indicators in the formula for calculating the impact of reinforcement of concrete on the performance of the cut. Based on the refined empirical dependence, which shows that the cutting of $1 \mathrm{~cm}^{2}$ of metal in time is comparable to the cutting of $100 \mathrm{~cm}^{2}$ of concrete, we obtain a coefficient of reduction in labor productivity at different values of the percentage of reinforcement of concrete. The table of values of $k_{r}$ is made at a step of rebars of $200 \mathrm{~mm}$, at quantity of rebars-10 pieces (two grids on $5 \mathrm{pcs}$ ), at length of a cut of $90 \mathrm{~cm}$, at depth of a cut of $30 \mathrm{~cm}$ (figure 2).

Table 4 presents the coefficient of reinforcement of concrete.

Table 4. Coefficient of reinforcement of concrete

\begin{tabular}{|c|c|c|c|c|c|}
\hline No. & $\begin{array}{c}\text { Diameter of } \\
\text { rebar, } \mathrm{mm}\end{array}$ & $\begin{array}{c}\text { Reinforcement, } \\
\%\end{array}$ & $\begin{array}{c}\text { Conditional } \\
\text { additional cut, } \mathrm{m}^{2}\end{array}$ & $\begin{array}{c}\text { Square of single } \\
\text { rebar, } \mathrm{cm}^{2}\end{array}$ & $k_{r}$ \\
\hline 1 & 2 & 3 & 4 & 5 & 6 \\
\hline 1. & 12 & 0,418 & 0,1130 & 1,1304 & 0,7105 \\
\hline 2. & 14 & 0,644 & 0,1739 & 1,7392 & 0,6136 \\
\hline 3. & 16 & 0,744 & 0,2009 & 2,0096 & 0,5745 \\
\hline 4. & 18 & 0,942 & 0,2540 & 2,5400 & 0,5192 \\
\hline 5. & 20 & 1,162 & 0,3140 & 3.1400 & 0,4655 \\
\hline 6. & 22 & 1,279 & 0,3460 & 3,4600 & 0,4426 \\
\hline 7. & 24 & 1,674 & 0,4521 & 4,5216 & 0,3750 \\
\hline 8. & 26 & 1,965 & 0,5306 & 5,3066 & 0,3375 \\
\hline 9. & 28 & 2,279 & 0,6154 & 6,1544 & 0,3068 \\
\hline 10. & 30 & 2,616 & 0,7065 & 7,0650 & 0,2783 \\
\hline 11. & 32 & 2,977 & 0,8038 & 8,0384 & 0,2523 \\
\hline 12. & 36 & 3,768 & 1,0173 & 10,1736 & 0,2109 \\
\hline 13. & 38 & 4,198 & 1,1335 & 11,3354 & 0,1928 \\
\hline
\end{tabular}




\begin{tabular}{|l|l|l|l|l|l|}
\hline 14. & 40 & 4,651 & 1,2560 & 12,5600 & 0,1776 \\
\hline 15. & 42 & 5,128 & 1,3847 & 13,8474 & 0,1636 \\
\hline 16. & 44 & 5,640 & 1,5197 & 15,1976 & 0,1516 \\
\hline 17. & 46 & 6,152 & 1,6610 & 16,6106 & 0,1398 \\
\hline 18. & 48 & 6,698 & 1,8086 & 18,0864 & 0,1304 \\
\hline
\end{tabular}

This coefficient is equally applicable for diamond cutting (disk and wire sawing), and for diamond drilling. The theoretical calculation of the coefficient of influence of the depth of cut $k_{d}$ on the performance of the equipment was made based on the analysis of the arc length of the contact of the diamond disk with the cut material. In practice, when performing a deep cut (from 30 to $70 \mathrm{~cm}$ ), it is necessary to consistently use diamond disks of three sizes(from $800 \mathrm{~mm}$ to $1200 \mathrm{~mm}$ and ending with $1600 \mathrm{~mm}$ ). These discs will differ not only in the radius but also in the length of the arc of contact with reinforced concrete (figure 3).

Since, with the increase in the length of the contact area increases the number of diamonds involved in the cutting process, this causes increasing of resistance to cut, therefore there is a decrease in productivity. The arc length for each disc size can be calculated using the formula:

$$
L=\int_{a}^{\partial} \sqrt{1+\left(y^{\prime}\right)^{2}} d x
$$

We are interested in meanings for the cutting depth of 30,50 and $70 \mathrm{~cm}$. As a result of calculations we obtain $k_{d 30}=0,6550$, and $k_{d 50}=0,5135$. In tabular form, the value of the coefficient depending on the depth of cut is presented in table 6.

Table 6. The value of the coefficient of dependence on the depth of cut

\begin{tabular}{|c|c|c|}
\hline No. & Depth of cut, $\mathrm{m}$ & $k_{d}$ \\
\hline 1. & 0,3 & 1,0000 \\
\hline 2. & 0,5 & 0,6550 \\
\hline 3. & 0,7 & 0,5135 \\
\hline
\end{tabular}

The coefficient of the drilling direction of the $k_{d d}$ is derived empirically and shows the difference in the time of penetration in vertical and horizontal drilling. The complexity of drilling in horizontal and inclined position is higher than in vertical drilling. The coefficient values are presented in table 7.

Table 7. Coefficient of the drilling direction $k_{d d}$

\begin{tabular}{|l|l|c|}
\hline No. & Direction of drilling or disc wall sawing & $k_{d d}$ \\
\hline 1. & Vertical (excluding ceiling position cut) & 1,0000 \\
\hline 2. & Horizontal and inclined (including ceiling position cut) & 0,9091 \\
\hline
\end{tabular}

All in all coefficients give planners opportunity to make draft calculation and include concrete drilling and sawing in projects even having no experience in such technology at all.

\section{References}

1. Ackerman M. “Specialsägemaschinen”, Diamant Report 1, 2002, p. 4 - 6. 
2. Autenried W. "Die schienengefürte Unuversalsäge”, Diamant Report 1, 1999, p. 12 13.

3. Bienert P. "Kreissägen von Beton mit Diamantwerkzeugen", Dissertation, TU Hannover, 1978.

4. Dennison D. "Diamont blades: Softer doesn't always mean faster" Concrete Openings, Magazine of the Concrete Sawing and Drilling Association. December 2017, p. 40 41.

5. Denkena, B., Grove, T. Kempf, F., Dzierzawa, P.: (2018): Temperaturmessung beim Verzahnungsschleifen, Schleiftechnik 2018, S. 12-16.

6. Denkena, B., Grove, T., Müller-Cramm, D., (2018): Strategien zur Minderung des Werkzeugverschleißes beim Schleifen von PCBN, Schleifseminar 2018, 18 Seiten.

7. Hanzach E. "Dismantling of a Steel Bridge", World of Grinding and Cutting, Journal of Cutting, Drilling and Grinding Technologies, 124, 1998, p. 22.

8. Harti M. "Sanierung Ausbau KVA Niederurnen", Diamant Report 1, 2001, p. 12 - 13.

9. Jindra J. "Vynalezy a pokroky", Praga, 1914.

10. Kossolapov A. "Basis of concrete drilling and sawing technology in construction Moscow, ASW, p. 108-109.

11. Kossolapov A. "Diamonds at work" http://kunskapslänken.se/2012/02/09/diamondsat-work/ 02.2012.

12. Marques P., Pernollet G. "Rationeller Betonabbau am San Bernardino Autobhantunnel A13", Diamant Report 1, 1999, p. 1 - 7.

13. Marques P. "Ecken sägen statt bohren”, Diamant Report 1, 2001, p. 10 - 11.

14. Rick Norland P.E. "Deep and Large Hole Drilling", Concrete Openings, Magazine of the Concrete Sawing and Drilling Association. September 2003, p. 34 - 37.

15. Plattner H. "Easy Drilling" Tyrolit's Revolutionary Core Drill”, World of Grinding and Cutting, Journal of Cutting, Drilling and Grinding Technologies, 128, 2000, p.p. 10 13.

16. Plattner H. "Easy Drilling” Tyrolit's Revolutionary Core Drill”, World of Grinding and Cutting, Journal of Cutting, Drilling and Grinding Technologies, 128, 2000, p.p. 10 13.

17. Rick Norland P.E. "Deep and Large Hole Drilling”, Concrete Openings, Magazine of the Concrete Sawing and Drilling Association. September 2003, p. 34 - 37.

18. Straninger M. "New diamond wire", World of Grinding and Cutting, Journal of Cutting, Drilling and Grinding Technologies, 128, 2000, p.p. 10 - 13.

19. Wehiger N. "Simultaneous Cutting of thick-walled Steel Frames and Concrete", World of Grinding and Cutting, Journal of Cutting, Drilling and Grinding Technologies, 124, 1998, p. 23

20. Wright D.N., Cassapi V.B. "Factors influencing stone sawability", Industrial Diamond Review 2, 1985. 